\title{
Should Students Be Able to Opt Out of Evolution? Some Philosophical Considerations
}

\author{
Robert T. Pennock
}

Published online: 21 April 2010

(C) Springer Science+Business Media, LLC 2010

\begin{abstract}
One new development in the ongoing creationism/ evolution controversy has been the proposal to institute optout policies that would allow creationist parents to exempt their children from any instruction involving evolution. By way of an explanation of some of the philosophical issues at play in the debate over evolution and the nature of science, this article shows the educational folly of such policies. If evolution is taught properly, it should not be possible to opt out of it without opting out of biology. Moreover, if Intelligent Design creationist criticisms of evolution and scientific naturalism were taken as the basis for opting out, then the effect would be even more radical and would require opting out of science entirely.
\end{abstract}

Keywords Evolution education · Intelligent design creationism $\cdot$ Nature of science $\cdot$ Opt-out policies

\section{Opting Out of Evolution}

In 2009, a proposed bill in Alberta, Canada included a provision that would require schools to notify parents in advance if a class dealt explicitly with religion, sexuality, or sexual orientation and allow them to have their child excluded from the discussion. The provision made headlines when the provincial Premier in Alberta confirmed that this would allow parents to exclude their child from a class when evolution came up. Said one opposition leader, this

R. T. Pennock $(\bowtie)$

Lyman Briggs College and Depts. of Philosophy \& Computer

Science, E-30 Holmes Hall, Michigan State University,

East Lansing, MI 48825, USA

e-mail: pennock5@msu.edu was going to hurt Alberta's international image and make it "sound like Arkansas." (CBC News 2009a)

A similar controversy had arisen in the United States in Oklahoma earlier in the year. A proposed "Science Education and Academic Freedom Act," which followed the script of other so-called "Academic Freedom" bills that Intelligent Design Creationists (IDCs) were lobbying for, included language that said students could not be "penalized in any way because [they] subscribe to a particular position" on scientific theories. The key aim of the bill was to allow creationist material that would critique evolution and other scientific theories, and opponents of the bill pointed out that it also would allow students to opt out even of particular test questions if they objected to evolution (Cavanagh 2009).

In Florida, the River of Life Church, an Evangelical Christian church in Niceville, assists its parishioners in asking for their children to opt out of a wide variety of school activities that they disapprove of. By clicking check boxes on its helpful web page, the church automatically generates a letter for parents to print which instructs a school to excuse their child from activities such as Halloween, "Sexual Education," "Homosexual, or Tolerance Training," or "Green Days, Saving the Earth." Another check box creates the following opt-out request for any class discussions on evolution:

While many of our local teachers seek to be sensitive to this topic, the text books and matierials $[$ sic $]$ often pertrayed $[s i c]$ it more as fact, rather then [sic] popular scientific theory. This presentation is often a biased one, refusing to look at even the possibilities that other views present. And it is biased even in the face of evidance [sic] to the contrary. I do not want my child to be apart [sic] of such discussions. Please provide an alternative activity for my child (River of Life Church 2009). 
There are a variety of reasons why creationists want to be able to have their children opt out of evolution. One basic reason seems simple, at least at first glance. They see evolution as contradicting their understanding of the story of creation as it is told in their sacred text, and they want to teach that religious account instead. This is true, as far as it goes, but in fact, their objections to evolution go far beyond a dispute about the facts of biological origins. As I have explained in detail elsewhere, at stake for most creationists is morality itself and the possibility of meaning and purpose to life (Pennock 1999). But they don't stop with evolution; most creationists also reject key findings in geology, astronomy, anthropology, and many other sciences as well. Even more radically, the new creationists also reject essential elements of scientific methodology, which they claim to be a naturalistic metaphysical dogma. Instead of natural science, they propose a theistic science that is based in their understanding of Biblical truth. As Intelligent Design Creationist William Dembski puts it, "any view of the sciences that leaves Christ out of the picture must be seen as fundamentally deficient." (Dembski 1999, p. 206)

No science teacher or administrator with integrity could allow creationism to be taught in a science class, but given the headaches that creationists cause, it is not hard to see how one might be tempted to allow an opt-out policy as a practical expediency. Many schools already have policies that allow students to opt out of sex education classes, for instance. Why not meet creationists halfway and treat evolution the same way?

Eugenie Scott and Glenn Branch have addressed this question of opt-out policies specifically including evolution (policies that they wittily label with the pointed acronym OOPSIE), showing some of the reasons why this proposed "compromise" is ill advised. At the very least, having students bob in and out whenever "the dreaded e-word" comes up is disruptive to the course as a whole. Leaving aside the educational loss to students themselves and the additional burden on teachers, such a policy would harm school districts as well, since students who do not learn about evolution will perform worse on the statewide examinations and in colleges. But more significantly, given that evolution pervades or at least ought to pervade biology education, there is no alternative to learning about it and no activity that would be an adequate substitute (Scott and Branch 2008).

This last point deserves to be developed further; that is the task of the first part of this essay. Creationists seriously mislead the public about the foundational significance of evolution within biology by portraying it as a "controversial theory." The problem is not just that they make factual errors about evolution; even more significant are their conceptual errors about the nature of evolutionary biology and about science. Understanding these philosophical issues behind the creationism controversy can not only show the educational folly of such opt-out policies, but also help instructors teach about evolution and science in general more effectively.

To be clear, this paper will not take a stand on the question of whether students are or should be legally allowed to specifically opt out of evolution. One can, of course, foresee the morass of practical problems that opening the door to such personal exemptions would cause for schools. But one might argue that the law should nevertheless allow for at least deep-seated religious exemptions in a similar way that the Supreme Court allowed the Old Order Amish, whose distinctive and comprehensive religious way of life is fundamentally at odds with the modern world, to opt out of compulsory education past eighth grade (Wisconsin v. Yoder, 1972). This may seem extreme, but we will later see a significant sense in which the creationists' religious objections are similarly comprehensive and deep-seated. However, addressing the legal question would take us too far afield. Rather than arguing whether students are or should be allowed to opt out of just evolution, our question is whether they should be able to do so. My contention is that, if evolution is taught properly, then it should not be possible for a student to opt out of it without opting out of biology as a whole. Moreover, I want to argue that when the systematic religious objections that creationists have to evolution are fully understood, one sees that the issue involves not just biology but all of science. Appreciating some of the philosophical aspects here will help science educators teach their subject in a manner that will better serve all their students.

\section{Teaching Evolution the Right Way}

So how should evolutionary biology be taught? It should be taught like any science should be taught, namely, so as to reveal the nature of science. The main point for teachers to keep in mind is that science focuses on investigating the causal structure of the natural world. It is the lawful relations between causes and effects that determine the regularities and patterns that we aim to explain. For example, the molecular patterns that chemists investigate are the result of combinations of chemical elements that interact in ways that become more and more understandable as these scientists uncover the relevant chemical processes.

Biology works the same way; it focuses on patterns of biological phenomena and the biological causal processes that produce them. Faced with some interesting phenomenon, be it the geographical distribution of species or the functioning of organs in the body, biologists will seek to explain the relevant pattern by looking for the causes that 
produced it. The interesting thing about biology is that there are two different kinds of causes that are relevant. The first kind involves the immediate nearby causes of the patternwhat is producing a particular effect right now, for instance. These are called the proximate causes. By themselves, proximate causes sometimes seem disjointed, but a second form of explanation helps unify them by pointing to deeper historical causes. Philosophers usually call these "ultimate" causes, though that term of art is somewhat misleading to non-professionals because such causes need not be ultimate in the vernacular sense of the term (sometimes the term "distal" is used instead). In biology, these are the evolutionary causes of a pattern.

There are a variety of ways in which evolutionary causes come into play, but two of the most important are the principles of common descent and natural selection. Biological patterns that would otherwise seem puzzlingly contingent are suddenly brought together and made understandable once evolutionary history is taken into account. It is common descent that explains, for example, the distinctive patterns of biogeography from the level of continents to that of islands. And it is natural selection that explains the striking universal patterns of adaptation between organisms and environment. Put simply, every proximate biological cause has an ultimate evolutionary cause that helps explain how it came to be, which is why evolutionary theory is a basic unifying explanatory framework for all of biology.

It is in this sense that one should understand the famous quotation from Theodosius Dobzhansky that nothing in biology makes sense except in the light of evolution (Dobzhansky 1973). Scott and Branch had this exactly right. "A teacher who tries to present biology without mentioning evolution" they quipped, "is like a director trying to produce Hamlet without casting the prince" (Scott and Branch 2008, p. 148). When biology is taught properly, one should find evolution across its entire curriculum.

For various reasons, biology textbooks have not always been organized in a way that clearly shows this. They explain evolution explicitly in one dedicated chapter or section but elsewhere simply take it for granted. Professional biologists already understand how evolution is foundational to biological explanation and so do not always make it explicit. However, one happy result for science education of creationist attacks is that these have awakened biologists to the need to improve textbooks and classroom instruction to make this fact more obvious. Scientists are working now to generate pedagogically useful examples and to demonstrate practically how teachers can better highlight evolution throughout the biological disciplines. We may look forward to more textbooks where evolution will appear explicitly not just in its own section, but also throughout discussions of organismal, cellular, and molecular biology. Taught properly, evolution should be visible everywhere in biology education. It is in this straightforward, structural sense that a student taking any biology course should not be able to opt out of evolution - when biology is taught in an integrated fashion, evolution is everywhere and is thus unavoidable.

\section{Revealing the Nature of Science}

However, teaching biology properly to reveal its underlying explanatory framework is only one part of what we need to do. As I have argued previously, the best science teaching reveals not just the science of nature but also the nature of science (Pennock 2005).

One especially important aspect of this idea is that teaching evolution properly, so as to reveal its role as a foundational explanatory framework in biology, immediately illuminates how scientific explanations work. Science does not stop with mere description; it is not just a catalog of facts. Although one still occasionally hears a scientist repeat the old claim that science does not explain but only describes, this is a long-discredited view of science. In science, one explains effects by citing causes, and that is exactly what is going on when one explains biological patterns in terms of common descent, natural selection, or some other from the suite of causes that are part of evolutionary theory.

A second issue has to do with the sense in which the term theory is used in science. Unlike the colloquial meaning of the term, theory is not the opposite of fact. The opt-out request letter from the River of Life evangelical church provides just one example of this common misunderstanding. Rather, as we have seen above, theory refers to the framework of causal laws and concepts that help explain particular empirical phenomena. Once hypotheses about these have been tested and confirmed, then they are no less factual than the things that they explain.

The idea of testability deserves special emphasis when we teach about science, for it is the key feature of scientific methodology. Too often the way that science is taught - as lists of facts and formulae to be memorized - gives students a false impression about why scientists accept these findings. Unlike religious dogma, it is not by authority that scientific conclusions are to be accepted. To the extent that students are told only what the conclusions are, they will likely fail to appreciate what is distinctive about science, namely the means by which these conclusions were tested and confirmed by evidence.

This point is also related to the important notion of observability in science. Creationists seem to believe that the only way to test something is by observing it directly, and they think that evolution isn't observable. They are wrong on both counts. 
First of all, the idea of observation in science is not the naive notion that creationists assume when they recommend that students challenge their instructors who teach about the evolution by asking them "Were you there?" (Simon 2006). The faulty assumption behind this impertinent challenge is that one has to observe something with one's own eyes for it to qualify as science. If direct observation is the only way to test a hypothesis, then no scientist is in any position to know how creation occurredonly God is. That is the creationist view, of course. This seriously misunderstands the relationship between testability and evidence in science. After all, most of the most important discoveries in science involve things that cannot be seen directly. The real way in which observability is a requirement in science is not that scientists may countenance only observable entities, but that scientists have to rely upon observational evidence. To give just a simple example, scientists do not need to observe sub-atomic particles directly to conclude that they exist; rather, they confirm their existence (and much more about their particular properties) by checking their hypotheses about them against predicted, observable patterns of physical data. Confirming evolutionary hypotheses, even about the distant past, works in exactly the same way.

Second, creationists are wrong even about the basic facts regarding the evidence for evolution: in many cases, evolution is directly observable. The evolutionary processes that Darwin discovered continue to operate and may be observed all around us. My colleague Richard Lenski, whose own long-term investigation of evolving populations of E. coli set a new standard for direct evolutionary experimentation, likes to point out that such observations of evolution in action are not really new but have been taking place since Darwin's own time. He tells, for instance, of Rev. William Dallinger, a Methodist minister who also was skilled in microbiology, who conducted a six-year evolutionary experiment using protozoa and excitedly wrote to Darwin about how his findings "palpably demonstrate your great doctrine" (Lenski 2009). Today, investigating evolution in action is becoming more and more important for practical purposes in fields ranging from agriculture to medicine to zoology. Evolutionary Science and Society: Educating a New Generation (Cracraft \& Bybee 2005) is a useful resource for educators to get a sample of this research, as is David Mindell's The Evolving World (Mindell 2006). Moreover, we are now at a point where, by instantiating the evolutionary mechanism directly in an artificial-life environment in a computer, evolutionary hypotheses can be tested even more precisely and effectively. One of my own efforts along these lines has been to develop and test an educational version of such an evolving a-life systemAvida-ED - that allows students in undergraduate courses to observe evolution in action for themselves (Pennock 2007b; Speth et al. 2009).

Creationism consistently fails to follow science's methodological rules and so does not begin to qualify as science. This failure starts with its most basic claim that biological complexity is explained by the design of a supernatural agent, not evolutionary or indeed any natural causes. But appeal to miraculous powers is no scientific explanation. Because by definition, the miraculous has no limits, it rules out no observable pattern - any data may follow in any situation. Something that could "explain" anything in any situation really explains nothing at all. The problem is not just that special creation is a bad scientific theory; creationism offers no positive theory at all. And it is not just that creationists are notoriously slippery about their views; rather, there is no conceptual friction at all, to continue the metaphor, by which one may hold onto a purported supernatural power and say what likelihood it confers upon any possible state of affairs. It thus fails to be testable either by direct or indirect observational evidence. It is because of such considerations that scientific methodology is restricted to appeals to natural causes; methodological naturalism is a basic principle of science because it is essential for the very idea of empirical evidence (Pennock 1999).

This is not to say that supernatural powers do not or could not possibly exist. Science is not in the business of proving or disproving metaphysical claims. Religious belief in a supernatural creator may rest upon theological arguments or upon faith, but it is wrong to pretend, as creationists do, that supernatural design is proven by science. Indeed, this defining element of creationism is enough to allow a reasonable person to determine that it is not science but a religious view. This is exactly what the courts have determined every time that the issue has been tried, whether the form of creationism being considered is Creation-Science or Intelligent Design. The ruling against Intelligent Design Creationism in the Kitzmiller v. Dover case should be mandatory reading for anyone who wants to see why creationism does not belong in public schools (Kitzmiller v. Dover 2005).

\section{Creationism: A Religious Controversy}

Having consistently failed to satisfy the courts that including their views in public school science classes is constitutional, creationists now lobby for schools to "teach the controversy" and have students learn the "strengths and weaknesses" of evolution under the guise of "academic freedom" (Matzke et al. 2006; Pennock 2007a; Branch and Scott 2009). Their strategy here, of course, is to open the door to their usual objections to evolution without mention- 
ing their movement by name. This approach trades on a basic ambiguity about the nature of the controversy.

The proper response to such efforts is "What controversy?" Anyone who understands the nature of science and the centrality of evolution within biology knows that there is not a scientific controversy about evolution as creationists claim. There is a Creationism/evolution controversy, but it is a religious controversy. However, it is not a religious controversy in the simplistic sense of "science vs. religion" as the story is commonly played out in the media. As we shall see, it is a controversy of religion vs. religion; in particular, the creationism controversy is based in fringe sectarian views that oppose one another as well as mainstream theology.

The defining element of creationism is the rejection of evolution in favor of some supernatural act of creation. In a simple sense, that does make creationism a religious attack on science, but the controversy is really much more complicated and much more interesting, for it is critical to remember that creationists come in a wide variety of stripes. Young-earth creationists (YECs) such as the well-known "Creation-Science" advocates, who hold that the world is not much more than 6,000 years old, are probably the most common anti-evolutionists today, but old-earth creationists (OECs) see no theological problem with accepting the standard geological chronology of billions of years. Intelligent Design Creationism (IDC) attempted to unite YECs and OECs under a "big tent" of anti-evolutionism by agreeing to temporarily set aside their fundamental disagreement about the age of the earth, but this political alliance is fragile and already beginning to come apart at the seams. IDC leader William Dembski, who for many years refused to state his own view on the matter, was recently forced to publicly announce "I am an old earth creationist" and defend himself against a theological challenge to his religious orthodoxy by a Baptist pastor who accused him of being a theistic evolutionist (Dembski 2009). And of course, there are non-Christian creationists who have their own preferred religious account of creation.

The above (incomplete) taxonomy of varieties of creationism shows the fallacy of suggesting that one should teach "both sides" of the "controversy." There are any number of non-scientific views whose proponents are eager to have them included once the integrity of science classes is compromised by any form of creationism. The point to remember is that such sectarian religious views disagree with each other as much as they disagree with evolutionary science. It cannot be emphasized enough that avoiding irreconcilable religious differences in the public and political arena is a central reason for not allowing the establishment by the government of any religious view. This is as much for protection of freedom of religious belief as it is for the protection of the prerequisites for civil action in a democracy.
The taxonomy also shows a logical problem with the basic form of argument that creationists use. If there were only two possibilities, then one could support the second simply by refuting the first. This is the way creationists try to set up the issue, so that they only have to disprove evolution and do not have to give positive evidence for their own view. In the past, creationists did this by presenting what they called a "Dual Model," with Creation-Science and "Evolution-Science" as the only candidates. IDCs followed the same approach, though they relabeled the models as "Design Theory" and "Darwinism." But in no case is this an accurate account of alternatives. Creationists hope to win by default with only negative arguments, but given this false dichotomy, their argument does not get off the ground (Pennock 1999).

The problem of the false dichotomy shows up elsewhere as well, such as in the way that creationists set up the controversy in terms of science versus religion. The main way they do this is by treating evolution as though it were equivalent to atheism. This too is a long-standing view, going back to nineteenth-century Calvinist theologian Charles Hodge who wrote a book asking the question "What is Darwinism?" and answering: It is atheism (Hodge 1874). Creation-Science advocates said much the same thing and so do ID creationists today, though in a more devious way, by trying to build it into the very definition of evolution (e.g., Johnson 1993).

IDC's building atheism into the definition of evolution is devious not only because it is surreptitiously replacing science's methodological naturalism with a metaphysical view, but also because it inaccurately implies that there is no way to accept both evolution and belief in God. In fact, mainstream Christian theology sees no problem in accommodating evolution. Many statements from religious denominations and organizations that attest to this are helpfully compiled in the National Center for Science Education's book Voices for Evolution (Sager 2008). The significant point is that IDCs reject this mainstream Christian view, again creating a false dichotomy. As William Dembski put it "Design theorists are no friends of theistic evolution" [Emphasis in original] (Dembski 1996). The creationism controversy is not a simple matter of science versus religion but rather is a classic example of religion versus religion.

\section{Teaching Evolution the Wrong Way}

The considerations in the above sections should help science educators think not only about the right way to teach evolution, but also about how not to teach it (Pennock 2007a). Evolution is a science, not a religion, and when 
taught properly, this should be clear. IDCs are wrong to build a metaphysical form of atheism into the definition of evolution. Science educators must be careful, therefore, not to accept the creationists' way of framing evolution and not to inadvertently present it as a metaphysical view-that really would be quite inimical to science's methodological rules. If one were to teach evolution in this significantly wrong way, then creationists would have a legitimate complaint and would soon be joined by the mainstream moderates. However, it would not be very difficult for science teachers to avoid this mistake if science education regularly included some basic instruction about the nature of science. With a little care, there should be no legitimate reason for opt-out policies for any but the most extreme creationists.

As we have seen, the IDC objection to evolution is, at least if held consistently, religiously very deep-seated. It is a comprehensive worldview that opposes not just evolution but the entire scientific framework and advocates a premodern theistic science. The Notre Dame philosopher and early IDC advocate Alvin Plantinga articulated this kind of view in a paper about the teaching of creation and evolution in the schools. Parents, he said, might have comprehensive beliefs that are opposed to those of science. They have a basic right, he claims, not to have their children taught comprehensive beliefs that contradict their own (Plantinga 2001). Plantinga used this as part of an argument for requiring parents' alternative beliefs, such as creationism, to be included in science classes, rather than as an argument for allowing a student to opt out of evolution, but his idea could easily be redeployed in favor of allowing opt-out policies. I have previously discussed the problems with the specifics of Plantinga's argument (Pennock 2002) and will not repeat those here.

My point here is just the straightforward one that IDC is, in Plantinga's sense, a comprehensive religious belief. One sees this, for instance, in the leaked IDC manifesto the "Wedge Document"-its call for a revolutionary theistic science and a radical transformation of modern culture that is based in their understanding of the Bible is the governing principle of the ID movement (Discovery_Institute 1998; Downey 2006). Seen in this way, this is indeed very similar to the case of the Amish as adjudicated in Wisconsin v. Yoder (1972). Again, I am not taking up the question here of whether students are or should be legally allowed to opt out. I simply want to point out what this comes to, given what we have seen about evolution and the nature of science. If methodological naturalism is a problem, it is not in any special sense a problem for evolution, for it is essential to all of science. The IDC attack on science's naturalistic methodology is an attack on science itself. If this is the basis for an opt-out policy, then it means opting out of science entirely.

\section{Conclusion}

In the Alberta case with which we began this article, the concern about the possibility of an opt-out policy for evolution was quickly resolved. The Alberta Minister for Human Rights stepped in to explain that the opt-out proposal involved being able to opt out of religious instruction, not out of some particular part of the curriculum because of religious beliefs.

So the thought that somebody can get out of evolution using the fact that it's against their religious beliefs is not correct....Evolution is not a part of religious studies, it's part of science curriculum, and there is nothing that will change that going forward (CBC News, 2009b).

This is a rational response. Evolution should be taught robustly as a core part of the science curriculum. It is a wellconfirmed conclusion of standard scientific methodology, and for most mainstream Christians, it is accepted as such. So long as evolution is not taught improperly as a metaphysically atheist view, there should be no danger of mistaking it for a part of religious studies. The Canadians got this exactly right.

Unfortunately, the controversy is not likely to be solved so simply in the United States. In Oklahoma, the proposed legislation that might have led to schools having to heed such requests failed to pass the Senate Education Committee, but just barely, in a narrow seven to six vote (Hoberock 2009). In Niceville, FL, the River of Life Church continues to help its members try to opt out of evolution. Given the extreme and expansionist views that drive the creationist movement, we should not expect that creationists will give up their battle.

Perhaps the time will come when the courts conclude that creationist parents should be allowed to have their children opt out of evolution. What I have argued in this essay is that if evolution is taught properly, opting out of evolution really means opting out of biology. And if parents object not just to evolution, but also to science's naturalistic methodology, as ID creationists do, then they need to know that this means opting out of science entirely. Such a radical departure from the real world makes the Amish look like amateurs.

\section{References}

Branch G, Scott EC. The latest face of creationism. Scientific American. 2009;300(1):92-9.

Cavanagh S. Oklahoma evolution. February: Education Week; 2009. 17.

CBC News. Evolution classes optional under proposed Alberta law. CBC News, Toronto, Canada. 2009a. http://www.cbc.ca/canada/ calgary/story/2009/04/30/cgy-bill-evolution-law-alberta-classesteachers.html. Accessed 30 April 2009. 
CBC News. Proposed Alberta law doesn't make evolution classes optional: minister. CBC News, Toronto, Canada. 2009b. http:// www.cbc.ca/canada/calgary/story/2009/05/04/cgy-evolutionalberta-human-rights.html. Accessed 4 May 2009.

Cracraft J, Bybee RW, editors. Evolutionary science and society: educating a new generation. Washington DC: Biological Sciences Curriculum Study; 2005.

Dembski WA. What every theologian should know about creation, evolution, and design. Access Research Network. 1996. http:// www.arn.org/docs/dembski/wd theologn.htm.

Dembski WA. Intelligent design: the bridge between science and theology. Downers Grove: InterVarsity Press; 1999.

Dembski WA. Comment to Johnny T. Helms. In: Our sovereign joy. 2009. http://oursovereignjoy.blogspot.com/2009/12/book-reviewwilliam-dembskis-end-of.html. Accessed 27 Dec 2009.

Discovery_Institute. The wedge strategy. 1998. http://www.stephen jaygould.org/ctrl/archive/wedge_document.html. Accessed May 1999.

Dobzhansky T. Nothing in biology makes sense except in the light of evolution. Am Biol Teach. 1973;35:125-9.

Downey R. Discovery's creation. Seattle Weekly News, Seattle, Washington. 1 February 2006.

Hoberock B. School science bill is killed. Tulsa World, Tulsa, OK. 17 Feb 2009.

Hodge C. What is Darwinism? New York: Scribner, Armstrong and Company; 1874.

Johnson PE. Darwin on trial. Washington, D.C.,: Regnery Gateway; 1993.

Kitzmiller, et al. v. Dover Area School District, et al. 2005. (400 F. Supp. 2d 707, Docket no. 4cv2688)

Lenski R. Evolution in action: a 21-year salute to Charles Darwin. In: Maloy S, Kolter R, editors. Microbial evolution 150 years after the origin of species. Washington, DC: ASM Press; 2009.

Matzke NJ, Gross PR. Analyzing critical analysis: the fallback antievolution strategy. In: Scott EC, Branch G, editors. Not in our classrooms: why intelligent design is wrong for our schools. Boston: Beacon Press; 2006. p. 57-82.
Mindell DP. The evolving world. Cambridge: Harvard University Press; 2006.

Pennock RT. Tower of Babel: the evidence against the new creationism. Cambridge: MA, The MIT Press; 1999.

Pennock RT. Should creationism be taught in the public schools? Sci Educ. 2002;11(2):111-3.

Pennock RT. On teaching evolution and the nature of science. In: Cracraft J, Bybee R, editors. Evolutionary science and society: educating a new generation. Colorado Springs, CO: Biological Sciences Curriculum Study; 2005.

Pennock RT. How not to teach the controversy about creationism. In: Jones LL, Reiss MJ, editors. Teaching about origins: taking account of creationism. New York: Peter Lang; 2007a. p. 59-74.

Pennock RT. Learning evolution and the nature of science using evolutionary computing and artificial life. McGill J Educ. 2007b;42(2):211-24.

Plantinga A. Creation and evolution: a modest proposal. In: Pennock RT, editor. Intelligent design creationism and its critics: philosophical, theological, and scientific perspectives. Boston: The MIT Press; 2001. p. 779-91.

River of Life Church. Partents [sic] Opt Out Letter. 2009. http://www. theriverfamilychurch.com/PublicSchool/OptOut.php. Accessed Dec 2009.

Sager C. (2008). Voices for evolution, 3rd edition. National Center for Science Education, Berkeley, CA. 2008. http://www.lulu.com/ items/volume_63/1709000/1709901/9/print/1709901.pdf.

Scott EC, Branch G. Overcoming obstacles to evolution education: the OOPSIE compromise - a big mistake. Evol Educ Outreach. 2008;1:147-9.

Simon S. Their own version of a Big Bang. Los Angeles Times, Los Angeles, CA. 11 February 2006.

Speth EB, Long T, Pennock RT, Ebert-May D. Using Avida-ED for teaching and learning about evolution in undergraduate introductory biology courses. Evol Educ Outreach. 2009;2(3):415-28.

Wisconsin v. Yoder. 406 U.S. 205. Certiorari To The Supreme Court Of Wisconsin. 1972. 